\title{
State of the art of the meiofauna of Brazilian Sandy Beaches
}

\author{
Tatiana Fabricio Maria ${ }^{1, *}$, Adriane Pereira Wandeness ${ }^{2}$, André Morgado Esteves ${ }^{2}$
}

\author{
${ }^{1}$ Universidade Federal do Estado do Rio de Janeiro, Departamento de Ecologia e Recursos Marinhos \\ (Av. Pasteur, 458. 22290-240. Urca, Rio de Janeiro-RJ. Brasil) \\ 2 Universidade Federal de Pernambuco Centro de Ciências Biológicas, Departamento de Zoologia \\ (Av. Prof. Moraes Rego s/n.50670-920. Cidade Universitária, Recife-PE. Brasil) \\ *Corresponding author: tatiana_fabricio@yahoo.com.br
}

\begin{abstract}
In Brazil, meiofauna studies began in the middle of last century, but they adopted a purely taxonomical approach, describing species from various zoological groups. After this first step, this benthic group was largely neglected until the end of the 20th century when ecological studies began. We here provide a brief review of present knowledge of the meiofauna found on Brazilian sandy beaches to provide information for ReBentos (Coastal Benthic Habitats Monitoring Network). Our methodology consisted of a bibliographic survey undertaken using different datasets (Web of ScienceTM, SCOPUS, Google Scholar and Lattes Plataform). For the survey, we considered only those studies published till early 2015. Our analysis showed that the number of meiofauna studies has increased over the last two decades, though they are mainly still concentrated on the Southeast of Brazil. These studies aim to explain the distribution pattern of the meiofauna of the intertidal region of sandy beaches. Based on the results, we presented a discussion of three main topics, i.e., (a) current knowledge of Brazilian sandy beach meiofauna, (b) sampling strategies for monitoring of the meiofauna, and (c) use of the meiofauna as a tool to assess climate change. We trust that this brief review will be useful as a starting point for the delineation of further climate change investigations into sandy beach meiofauna.
\end{abstract}

Descriptors: Sandy beaches, Meiofauna, Biodiversity, Monitoring, ReBentos, Climate change.

\section{RESUMO}

No Brasil, os estudos da meiofauna iniciaram em meados do século passado, com enfoque puramente taxonômico e voltado para a descrição de espécies de diferentes grupos zoológicos. Após essa fase inicial, a biota foi de certa forma esquecida até o final do século XX, quando os estudos ecológicos foram iniciados. Neste trabalho apresentamos uma breve revisão do conhecimento sobre a meiofauna de praias arenosas brasileiras, com o objetivo de fornecer subsídios para a ReBentos (Rede de Monitoramento dos Habitats Bentônicos Costeiros). Para isto, nossa metodologia envolveu um levantamento bibliográfico realizado a partir de diferentes bases bibliográficas (Web of Science ${ }^{\circledR}$, SCOPUS, Google Scholar e Plataforma Lattes), considerando artigos publicados até o início de 2015. As análises mostraram que o número de estudos da comunidade da meiofauna se intensificou nas últimas duas décadas, concentrando-se, principalmente, na região Sudeste do Brasil. Esses estudos visaram explicar os padrões de distribuição dos organismos na região intermareal. Com base nisso, apresentamos uma discussão desses resultados em relação a três principais temas: (a) conhecimento atual da meiofauna nas praias arenosas brasileiras, (b) estratégias amostrais para o monitoramento/estudo da meiofauna e (c) as perspectivas do uso da meiofauna na avaliação das mudanças climáticas. Espera-se que esta breve revisão possa ser usada como um estágio inicial para o delineamento de estudos que abordem o impacto das mudanças climáticas sobre a meiofauna de praias arenosas.

Descritores: Praias arenosas, Meiofauna, Biodiversidade, Monitoramento, ReBentos, Mudanças climáticas. 


\section{INTRODUCTION}

The term "meiofauna" is used to denote a heterogeneous group of benthic organisms that belong to a specific size class represented in almost all invertebrate phyla. In general, meiofauna organisms are able to pass through a mesh sieve of $500 \mu \mathrm{m}$ or $1 \mathrm{~mm}$ (size limits used depend on the author and the purposes of the study), but are retained by a mesh size of $62-38 \mu \mathrm{m}$ during an extraction procedure (GIERE, 2009). The term meiofauna was coined by MARE (1942) despite not having any special taxonomical or ecological significance (FENCHEL, 1978). Among the meiofaunal organisms, nematodes represent the majority of individuals in a sample of marine sediments (HEIP et al., 1985) and this is indeed true for the dynamic sandy beach ecosystem.

Sandy beaches are dynamic ecosystems driven by physical processes that shape the habitat for different functional and taxonomic groups. The term "sandy beach" can be used to describe a wide range of environments, from high-energy open-ocean beaches to sheltered estuarine sand flats (MCLACHLAN, 1983). Sandy beaches are, in general, dynamic environments occurring worldwide along ice-free coastlines, and located at the transition between the land and a waterbody such as an ocean, sea or lake. At first sight, this ecosystem seems to be a marine desert, due to the arid and sterile appearance of its sands. However, its wide range of habitats supports the establishment of a diverse biota, but even so this ecosystem is still less studied than most other coastal systems (DEFEO; MCLACHLAN, 2005). Most research on intertidal sandy beaches has been concentrated on macrofauna and on birds (see CORNELIUS et al., 2001; DEFEO; MCLACHLAN, 2005 for a review) and the less prominent sandy-beach meiofauna has received considerably less attention.

The first ecological study of the meiofauna in a sandy beach was undertaken on the German coast by REMANE (1933). After the development of specific methods to sample small benthos, the studies on the meiofauna have gained great importance in many parts of the world. At the present time, this group is being studied in habitats as diverse as alpine lakes and the deep-sea floor, tropical reefs and polar sea ice (GIERE, 2009). In terms of sandy beaches, the focus of the studies is mainly related to distribution patterns and few studies focus on more specific questions such as the response of nematodes to pollution and their role in the benthic food web (MARIA in press). In Brazil, meiofauna studies started in the middle of the last century, but were purely taxonomical, describing species of different meiofaunal groups (e.g. Platyhelminthes, Annelida, Mollusca, Nematoda, Kinorhyncha, Nemertea, Acari, Amphipoda, Ostracoda). After this taxonomical bloom, the meiofauna were neglected until the 1990s when ecological studies started (FONSECA et al., 2014).

Considering that meiofauna/nematodes have high abundance and diversity, widespread distribution, rapid generation time, fast metabolic rates, participate in the remineralization process, provide energy to higher trophic levels, they may be considered an excellent tool to evaluate environmental changes (ZEPPILLI et al., 2015). As one of the main goals of ReBentos (Coastal Benthic Habitats Monitoring Network) is to undertake a long-term monitoring of benthic biodiversity on the Brazilian coast in order to better understand the effects of environmental change on the biota, our aim is to provide a brief review of current knowledge of the meiofauna of sandy beach ecosystems which could be used as a starting point for future studies. They may, for instance, be used to provide data for the understanding of the effects of climate change on sandy beaches.

\section{MATERIAL AND METHODS}

A bibliographic survey was undertaken using Web of Science $^{\mathrm{TM}}$, SCOPUS, Google Scholar, and Lattes Platform databases, considering works published until early 2015. Initially papers published in scientific journals and only those with an ecological purpose related to the benthic meiofauna community of sandy beaches were selected and enumerated. Taxonomical articles were largely excluded from the analysis. The selected studies were classified according to 1) geographical region (North, Northeast, Southeast, and South), 2) primary focus (effect of an environmental variable, impact, methodology), 3) year of publication, 4) sampling frequency (months to years and number of sampling events during the study), and 5) number of beaches sampled. All this information may be found in Table 1.

\section{RESULTS}

Although the Brazilian coast extends for approximately $8000 \mathrm{~km}$ and contains approximately 2000 beaches, only $2.5 \%$ of these beaches had already been studied from the point of view of the meiofauna, resulting in 44 Brazilian sandy beach meiofauna studies covering the sampling of ten estuarine and 49 oceanic beaches. Of these ecological studies, 7 are exclusively related to 
Table 1. Overview of the sandy beach meiofauna studies in Brazil. Only community studies are listed.

\begin{tabular}{|c|c|c|c|c|c|c|c|}
\hline & Author & Year & Purpose & Periodicity & $\begin{array}{l}\text { Sampling } \\
\text { duration }\end{array}$ & $\begin{array}{c}\mathrm{n}^{\circ} \text { of beaches } \\
\text { studied }\end{array}$ & State \\
\hline 1 & MEDEIROS & 1984 & EVA & $?$ & $?$ & 1 & SP \\
\hline 2 & SILVA et al. & 1991 & EVA & SA & $2 \mathrm{~m}$ & 1 & RJ \\
\hline 3 & CARVALHO et al. & 1992 & EVA & $?$ & $?$ & 1 & $\mathrm{PE}$ \\
\hline 4 & MEDEIROS & 1992 & EVA & SA & $2 \mathrm{~m}(3 \mathrm{~d} / \mathrm{m})$ & 1 & SP \\
\hline 5 & ESTEVES et al. & 1995 & MET & YR & $1 \mathrm{~m}$ & 1 & $\mathrm{RJ}$ \\
\hline 6 & BEZERRA et al. & 1996 & EVA & MO & $12 \mathrm{~m}$ & 1 & PE \\
\hline 7 & BEZERRA et al. & 1997 & EVA & MO & $12 \mathrm{~m}$ & 1 & PE \\
\hline 8 & ESTEVES and FONSECA-GENEVOIS & 1997 & EVA & YR & $1 \mathrm{~m}$ & 1 & PE \\
\hline 9 & ESTEVES et al. & 1997 & MET & YR & $2 \mathrm{~m}$ & 1 & RJ \\
\hline 10 & SILVA et al. & 1997 & REV & n.a. & n.a. & n.a. & n.a \\
\hline 11 & WANDENESS et al. & 1997 & EIE & MO & $6 \mathrm{~m}$ & 1 & RJ \\
\hline 12 & ESTEVES and SILVA & 1998 & MET & YR & $1 \mathrm{~m}$ & 3 & RJ \\
\hline 13 & ESTEVES et al. & 1998 & EVA & DIA & $15 \mathrm{~d}$ & 1 & $\mathrm{RJ}$ \\
\hline 14 & WANDENESS et al. & 1998 & EVA & YR & $1 \mathrm{~m}$ & 1 & RJ \\
\hline 15 & SILVA et al. & 1999 & EVA & YR & $?$ & 4 & RJ \\
\hline 16 & CURVELO and CORBISIER & 2000 & EVA & MO & $6 \mathrm{~m}$ & 1 & SP \\
\hline 17 & CORGOSINHO et al. & 2003 & EVA & YR & $1 \mathrm{~m}$ & 2 & PR \\
\hline 18 & MOELLMANN and CORBISIER & 2003 & EIE & MO & $3 \mathrm{~m}$ & 2 & SP \\
\hline 19 & OLIVEIRA and SOARES-GOMES & 2003 & EIE & YR & $1 \mathrm{~m}$ & 1 & RJ \\
\hline 20 & SOMERFIELD et al. & 2003 & EVA & YR & $1 \mathrm{~m}$ & 1 & $\mathrm{PE}$ \\
\hline 21 & SOUZA-SANTOS et al. & 2003 & EVA & MO & $12 \mathrm{~m}$ & 1 & PE \\
\hline 22 & ESTEVES & 2004 & EVA & $\mathrm{MO}$ & $12 \mathrm{~m}$ & 1 & RJ \\
\hline 23 & TODARO and ROCHA & 2004 & EVA & YR & $1 \mathrm{~m}$ & 23 & SP \\
\hline 24 & PINTO and SANTOS & 2006 & EVA & SA & $2 \mathrm{~m}$ & 1 & $\mathrm{PE}$ \\
\hline 25 & ALBUQUERQUE et al. & 2007 & EVA & MO & $12 \mathrm{~m}$ & 1 & $\mathrm{RJ}$ \\
\hline 26 & NETTO et al. & 2007 & EVA & YR & $1 \mathrm{~m}$ & 1 & $\mathrm{SC}$ \\
\hline 27 & DI DOMENICO et al. & 2008 & EVA & SA & $2 \mathrm{~m}$ & 6 & SC and PR \\
\hline 28 & MARIA et al. & $2008 b$ & EVA & SA & $2 \mathrm{~m}$ & 3 & RJ \\
\hline 29 & GOMES and ROSA FILHO & 2009 & EVA & $\mathrm{BM}$ & $4 \mathrm{~m}$ & 1 & PA \\
\hline 30 & DA ROCHA et al. & 2009 & EVA & $\mathrm{S} / \mathrm{P}$ & $5 \mathrm{~m}$ & 3 & $\mathrm{PE}$ \\
\hline 31 & ROSA FILHO et al. & 2011 & EVA & YR & $1 \mathrm{~m}$ & 3 & PA \\
\hline 32 & MARIA et al. & $2013 a$ & EVA & SA & $2 \mathrm{~m}$ & 2 & RJ \\
\hline 33 & MARIA et al. & $2013 b$ & EXP & YR & $1 \mathrm{~m}$ & 1 & SP \\
\hline 34 & GOMES et al. & 2014 & EVA & $\mathrm{BM}$ & $4 \mathrm{~m}$ & 1 & PA \\
\hline 35 & VENEKEY et al. & $2014 a$ & EVA & $\mathrm{MO}$ & $12 \mathrm{~m}$ & 1 & $\mathrm{PE}$ \\
\hline 36 & VENEKEY et al. & $2014 b$ & EVA & $\mathrm{BM}$ & $4 \mathrm{~m}$ & 1 & $\mathrm{PE}$ \\
\hline 37 & NETTO et al. & 2014 & EVA & DIA & $1 \mathrm{~m}$ & 3 & PR \\
\hline
\end{tabular}

EVA: Environmental effect; EIE: Environmental impact effect; MET: Methodological; EXP: Experimental, YR: Yearly; SA: Semiannual; BM: Bimonthly; MO: Monthly; DIA: Daily; S/P: Periodicity undefined, m: Month (s) d: Day (s); d/m: Number of days per month; n.a.: Not applicable; ?: not informed; PA: Pará; PE: Pernambuco; PR: Paraná; SC: Santa Catarina; SP: São Paulo; RJ: Rio de Janeiro.

the effects of environmental variables on the population of a single nematode species (ESTEVES et al., 2003, 2004; MARIA et al., 2008a; VENEKEY et al., 2011) and tardigrades (CASTRO et al., 1999; DA ROCHA et al.,
2004; VERÇOSA et al., 2009) and have not been listed in Table 1 . The other 37 are related to meiofauna community studies. As can be seen from Figure 1, the number of ecological studies has increased over the last decade. 


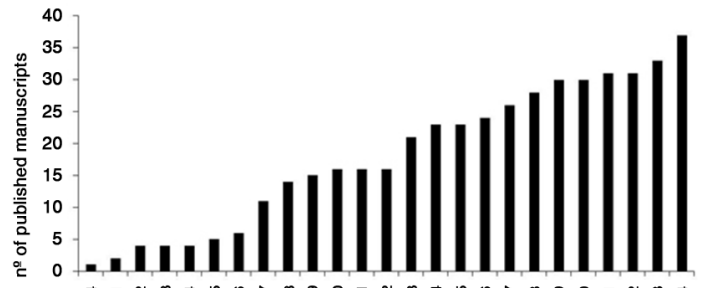

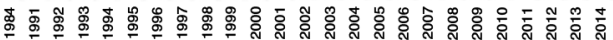

Figure 1. Cumulative percentage of the published manuscripts dealing with meiofaunal communities in sandy beaches.

Despite the great extension of the Brazilian coastline and the huge number of sandy beaches occurring along the coast, the sandy-beach meiofauna studies are restricted to only 6 Brazilian states: Pará, Paraná, Pernambuco, Rio de Janeiro, Santa Catarina and São Paulo (Table 1). However, the majority (19/37) are restricted to the Southeast region (Rio de Janeiro and São Paulo) followed by the Northeast region (Pernambuco) with 11 out of 37 studies. The studies in the Northern and Southern regions have been begun only in the last 5 and 10 years, respectively, and both together account for only 3 and 4 , respectively, of the 37 studies (Table 1 ).

\section{SOUTHEAST}

Much of what is known of the meiofauna of Brazilian sandy beaches is concentrated in this geographical area of Brazil. Thirty-seven of the sandy beaches in this area have been sampled, the majority of them being located in São Paulo (27). Most of these studies sought to understand the meiofauna distribution in relation to physicochemical variables. Granulometry is the variable that best explains the meiofauna community in almost all pristine areas (MEDEIROS et al., 1992; ALBUQUERQUE et al., 2007) as well as in organic polluted areas (MARIA et al., 2013a); however, the degree of organic pollution affects the fauna to a different extent according to the concerned taxa, e.g. copepods are more sensitive to pollution and decrease their density while nematodes increase it (OLIVEIRA; SOARES-GOMES, 2003). However, there are cases in which the granulometry of polluted beaches seems not to influence the meiofauna composition (WANDENESS et al., 1997). The intensive trampling of the sediment, when sandy beaches are used as recreational areas, can also have a negative impact on the meiofauna community (MOELLMAN; CORBISIER, 2003). Although nematodes are the dominant meiofaunal group in sandy beach sediments, gastrotrich is another meiofaunal group which has been extensively studied in this geographical area; this group also responds to variation in grain size, showing high diversity in beaches characterized by medium and fine sand associated with little detritus and clear water (TODARO; ROCHA, 2003).

Concerning the seasonal distribution, there is some evidence that temperature and salinity fluctuations over a seasonal cycle can influence the meiofauna distribution (ESTEVES et al., 1998).

The role of biological interactions on sandy beaches are less studied since it is commonly accepted that this structural factor is of less importance in dynamic environments (DEFEO; MCLACHLAN, 2005); as a result there are only two studies related to this issue as related to southeastern sandy beaches (see CURVELO; CORBISIER, 2000; MARIA et al., 2013b). In the former one, the variation of meiofauna density between the seasons is related to the habitat heterogeneity resulting from the presence of the algae Sargassum cymosum on the rocky shore whereas in the latter study the presence of polychaetes - Scolelepis - seems not to influence the nematode community.

\section{THE NORTHEAST}

This geographical area is the second in terms of published manuscripts, but only eight beaches have been investigated, all of which are, surprisingly, located in Pernambuco state. As a result, these beaches are all subject to the mesotidal regime although this is the only geographical region of the country which contains beaches of all three tidal regimes (macrotidal, mesotidal and microtidal).

All beaches studied here are suffering from some great anthropogenic impact, such as the disposal of organic waste and recreational use as the case of Tamandaré beach, Pina Bay and the Olinda Isthmus (BEZERRA et al., 1996; SOMERFIELD et al., 2003; SOUZA-SANTOS et al., 2003) or to a lesser extent, such as Coroa do Avião and Itamaracá beaches (PINTO; DOS SANTOS, 2006; DA ROCHA et al., 2009). The spatial and temporal distribution patterns of the meiofauna are associated with environmental variables, such as pigments, granulometry and rainfall (PINTO et al., 2006; SOUZA-SANTOS et al., 2003; VENEKEY et al., 2014b) in less organically polluted areas, whereas the biochemical demand for oxygen is an important environmental variable that explains the community structure's variation in organic polluted beach sediments (SOMERFIELD et al., 2003). 
There are also some studies that aim to assess the richness of copepods, tardigrades and nematodes for this geographical area (WANDENESS et al., 1998; DA ROCHA et al., 2009; VENEKEY et al., 2014a, 2014b). A higher richness of copepods is associated with the presence of sea grass on sandy beach sediments (WANDENESS et al., 1998), whereas a higher diversity of nematodes is associated with the beach level and it is found on a lower beach level (VENEKEY et al., 2014b). Unfortunately, no relationship between tardigrate richness and environmental variables was investigated (DA ROCHA et al., 2009).

\section{THE NORTH}

Knowledge of the meiofauna of the Northern region of Brazil is highly incipient, only four beaches having been sampled, and the respective studies focus on the assessment of the meiofauna of macrotidal beaches in contrast to studies undertaken in other geographical regions that sampled microtidal/mesotidal beaches. These studies also aimed to correlate the meiofauna distribution with physicochemical factors, it also being demonstrated that granulometric features are the main factor explaining its distribution - and consequently higher meiofauna density is found on exposed beaches than on sheltered ones (GOMES; ROSA FILHO, 2009; ROSA FILHO et al., 2011). Salinity also plays an important role in the temporal distribution, i. e. slightly higher richness and abundance occurred under the low salinity levels typical of the dry season of the year (GOMES; ROSA FILHO, 2009).

\section{The South}

The meiofauna studies produced in this geographical region of the country are very recent. The first meiofauna assessments date from the early $21^{\text {st }}$ century and were undertaken in subtidal areas in contrast to most meiofauna studies that emphasize the intertidal area (CORGOSINHO et al., 2003; NETTO et al., 2007). Nevertheless, the results obtained for meiofauna density were similar to those found for intertidal areas, that is to say, hydrodynamic regimes influence meiofauna density, which is higher in exposed areas than in sheltered ones (CORGOSINHO et al., 2003), as well as polychaete richness and diversity (DI DOMENICO et al., 2009). The effects of food subsidies on the meiofauna are another issue which has been investigated in this geographical area. Microphytobenthos seems to be an important food source for meiofaunal organisms since chlorophyll $a$ and feofitina $a$ correlated positively with meiofauna density (NETTO et al., 2007) in subtidal areas while there is no robust evidence for the use of surf phytoplankton as a food source for intertidal meiofaunal organisms (NETTO et al., 2014).

\section{DISCUSSION}

Although Northeast and Southeast regions continue to be the most intensively studied as regards the meiofauna, the number of beaches investigated varies greatly as between the states of these geographical regions. This scenario is somewhat different in the southeastern region where two states have been widely studied (São Paulo and Rio de Janeiro), accounting for 37 out of 65 Brazilian beaches studied. This picture is a reflection of the existence of the first centers of meiofauna investigation that were established in the southeastern and northeastern regions. Nowadays, there are experts working on the meiofauna and conducting studies in other geographical regions, such as the States of Pará and Paraná, but it was only possible after training a new generation of scientists.

It is difficult to establish an adequate estimate of the actual species diversity of meiofauna on Brazilian sandy beaches since many of the quoted studies are based on major taxonomical groups (phylum, classes, and so on). What is well known is that biodiversity is reduced in impacted areas, but some nematode genera/species are able to withstand very harsh conditions (MARIA et al., 2013a). However, the assessment of meiofauna diversity and density is ideal on reflective sandy beaches because this group of organisms is unique in the benthic community, being able to persist with high abundances (MOORE; BETT, 1989). This group is, therefore, an ideal bioindicator candidate for evaluating the impact of climate change on reflective sandy beaches since macrofauna organisms are commonly absent on this beach type (MCLACHLAN; BROWN, 2006). Nevertheless, for any long-term monitoring the sampling period $\mathrm{x}$ processing time of samples should be considered. In an ideal scenario, the sampling scheme should be monthly or fortnightly for at least a year since the combination of benthic life style and short life cycle, which can be of less than 15 days in some cases, leads the meiofauna to respond extremely fast to any possible environmental disturbances (SILVA et al., 1997). Therefore, using short sampling intervals would provide a more reliable seasonal variability of the meiofauna. But perhaps 
applying this sampling scheme would provide such a large number of samples by the end of the project as to make this strategy impracticable because the sampling process is so time-consuming. Thus, it is suggested that the sampling design should include at least two or more different seasons, covering both a dry and a wet season, for instance (MARIA et al., 2015).

Although concerns about global warming have dramatically increased, the impact of climate change on the meiofauna is still very little understood worldwide; only two studies having been undertaken on sandy beaches (see VANAVERBEKE et al., 2009; GINGOLD et al., 2013). In Brazil, the most closely related studies that could be used as elements for the understanding of climate change are those that analyze the natural life cycle of the meiofauna over an one-year period (e. g., ESTEVES et al., 2003; 2004; MARIA et al., 2008a; VENEKEY et al., 2011). However, these studies address the question to a single nematode population indicating that certain species increase their density during rainy or dry seasons.

Based on the results presented here, it can be seen that there are few long-term studies focusing on the meiofauna community (two out of six one-year studies), it is, therefore, still very premature to draw any conclusion concerning the relationship between climate change and the actual meiofauna distribution, diversity and density on Brazilian sandy beaches.

There is a lot of discussion concerning the use of the meiofauna community to understand the effect of climate change. An environmental impact assessment has shown that each meiofauna organism possesses distinct responses to the same kind of impact (MIRTO et al., 2012). We cannot, therefore, recommend that the assessment of the meiofauna community as a whole be used in this kind of study. Another negative aspect is related to the identification of the meiofauna organisms that requires the involvement of various experts. It is also time consuming since the observation of specific characters of tiny organisms calls for very laborious and careful observation always under the light microscope. A possible solution that may overcome these negative aspects is the choice of the most dominant group of the meiofauna to work in long-term monitoring programs or even to choose a very abundant species and follow its population structure.

Another important aspect for a very successful monitoring program is the standardization of the meiofauna sampling methodology in order to make the data comparable among geographical regions of the country. Brazil is a country of continental dimensions and it is to be expected that the effect of climate change should be distinct in each geographic area. Long-term monitoring is a valuable tool for understanding of the dynamic changes of the meiofauna as well as giving a better picture of the local biodiversity that can be compared with further scenarios of climate change.

In addition to a long-term monitoring program of the meiofauna in different geographical regions of the country, some simple laboratory and/or in situ experiments would be a worthwhile strategy. Some simple questions related to climate change could be raised and easily answered by means of experiments. We can give some examples: (1) What is the impact of sea level rise on the intertidal meiofauna community? (2) What is the behavior of the meiofauna community under high temperatures? (3) Can intense rainfall wash meiofauna into deeper sediment layers? There are already two successful approaches that predict the response of meiofauna under those changed climatic conditions (VANAVERBEKE et al., 2009; GINGOLD et al., 2013). In the former study it is shown that artificial rain can change the nematode community of European beaches, but the degree of change depends on the dynamic of the ecosystems, microtidal beaches being more affected than macrotidal ones. The latter study analyzed the influence of high temperatures on the nematode community and a loss of predator and omnivorous nematodes - important for the top-down control of the community, consequently leading to a change in the whole interstitial food web - was observed. Although results of experiments should be interpreted with caution since they are an oversimplification of what happens in the field, they can be a valuable tool to answer specific questions.

Our results show that the meiofauna assessments undertaken on Brazilian sandy beaches are unevenly distributed among the various geographical regions of the country thus making it very difficult to arrive at any conclusive statement concerning the influence of climate change on what is currently known of sandy beach meiofauna. We suggest that long term monitoring combined with an experimental approach constitute a valuable strategy to build a complete picture promising some understanding of the impact of climate change on sandy beach meiofaunal organisms. 


\section{ACKNOWLEDGMENTS}

The authors are grateful to the REBENTOS network that has dedicated special attention to the meiofauna group and especially to Dr Cecília Amaral who invited us to participate in the sandy beach working group (GT). We also wish to thank the two reviewers for their valuable comments on a previous version of the MS. A.M. Esteves (CNPq 312143/2013-3) wishes to express his gratitude for the research fellowship granted by the Conselho Nacional de Desenvolvimento Científico e Tecnológico - CNPq.

\section{REFERENCES}

ALBUQUERQUE, E. F.; PINTO, A. P. B.; PEREZ, A. D. Q.; VELOSO, V. G. Spatial and temporal changes in interstitial meiofauna on a sandy ocean beach of South America. Braz. J. Oceanog., v. 55, n. 2, p. 121-131, 2007.

BEZERRA, T. N. C.; FONSÊCA-GENEVOIS, V.; GENEVOIS B. Distribuição horizontal e vertical da meiofauna em uma região tropical intermareal (Istmo de Olinda Pernambuco Brasil). Trab. Oceanogr. Univ. Fed. Pernamb., v. 24, p. 249-264, 1996.

BEZERRA, T. N. C.; GENEVOIS, B.; FONSÊCA-GENEVOIS, V. Influência da granulometria na distribuição e adaptação da meiofauna na praia arenosa do Istmo de Olinda PE. In: SILVA, S. A.; GROHMANN, P. A.; ESTEVES, A. M. (Orgs.). Ecologia de Praias Arenosas do Litoral Brasileiro. Rio de Janeiro: Programa de Pós-Graduação em Ecologia da UFRJ, v. 3, p. 107-116, 1997.

CARVALHO, I. B.; FONSÊCA-GENEVOIS, V. G.; GENEVOIS, B. Heterogeneidade espaço-temporal da meiofauna na baía de Tamandaré-Pernambuco, Brasil. Biol. Bras., v. 4, n. 1, p. 43-56, 1992.

CORGOSINHO, P. H. C.; METRI, R.; BAPTISTA, C.; CALIL, P.; ARBIZU, P. M. M. Abundance and diversity of the sublittoral meiofauna on two sandy beaches under different hydrodynamic conditions at Ilha do Mel (PR, Brazil). Lundiana, v. 4, n. 2, p. 89-94, 2003.

CORNELIUS, C.; NAVARETTE S. A.; MARQUET, P. A. Effects of human activity on the structure of coastal marine bird assemblages in central Chile. Conserv. Biol., v. 15, n. 5, p. 1394-1404, 2001.

CURVELO, R. R.; CORBISIER, T. N. The meiofauna associated with Sargassum cymosum at Lazaro Beach, Ubatuba, São Paulo. Rev. Bras. Oceanogr., v. 48, n. 2, p. 119-130, 2000.

DA ROCHA, C. M. C.; FONSÊCA-GENEVOIS, V.; VICTORCASTRO, F. J.; BEZERRA, T. N. C.; VENEKEY, V.; BOTELHO, A. P. Environmental Interactions of Batillipes pennaki (Tardigrada, Heterotardigrada) in a tropical sandy beach (Itamaracá, Pernambuco, Brazil). Meiofauna Mar., v. 13, p. 79-86, 2004.

DA ROCHA, C. M. C.; VERÇOSA, M. M.; DOS SANTOS, P. J. P.; BARBOSA, D. F.; OLIVEIRA, D. A. S.; SOUZA, J. R. B. Marine tardigrades from the coast of Pernambuco, Brazil. Meiofauna Mar., v. 17, p. 97-101, 2009.

DEFEO, O.; MCLACHLAN, A. Patterns, process and regulatory mechanisms in sandy beach macrofauna: a multi-scale analysis. Mar. Ecol. Prog. Ser., v. 295, p. 1-20, 2005.
DI DOMENICO, M.; LANA, P. D. C.; GARRAFFONI, A. R. S. Distribution patterns of interstitial polychaetes in sandy beaches of southern Brazil. Mar. Ecol., v. 30, n. 1, p. 47-62, 2009.

ESTEVES, A. M. Free-living marine nematodes from Coroa Grande tidalflat (Sepetiba Bay, Rio de Janeiro, Brazil). Biociências, v. 12, n. 2, p. 185-186, 2004.

ESTEVES, A.M.; FONSÊCA-GENEVOIS, V. Microdistribuição da meiofauna na Coroa do Avião, Pernambuco Brasil, com referência especial à utilização de análise de autocorrelação espacial. Arq. Biol. Tecnol., v. 40, n. 1, p. 89-95, 1997.

ESTEVES, A. M.; DA SILVA, V. M. A. P. The behavior of sugar flotation technique in meiofauna extraction from different sand types. Tropic. Ecol., v. 39, n. 2, p. 283-284, 1998.

ESTEVES, A. M.; ABSALÃO, R. S.; DA SILVA, V. M. A. P. Padronização e avaliação da eficiência do método de flotação com açúcar na extração da meiofauna de uma praia de areia grossa (Praia Vermelha, RJ). Publ. Esp. Inst. Oceanogr. São Paulo, v. 11, p. 223-227, 1995.

ESTEVES, A. M.; ABSALÃO, R. S.; DA SILVA, V. M. A. P. The importance of costeffectiveness sampling in the study of intertidal sandy beach meiofauna. Trop. Ecol., v. 38, n. 1, p. 47-53, 1997.

ESTEVES, A. M.; BLOISE, C.; NOGUEIRA, C. S. R. Variação espaço-temporal da meiofauna ao longo de um período quinzenal, em um ponto fixo da Praia Vermelha, Rio de Janeiro. In: Simpósio de Ecossistemas Brasileiros, 4. Anais, v. 4, p. 179-193, 1998.

ESTEVES, A. M.; MARIA, T. F.; WANDENESS, A. P. Population structure of Oncholaimus cobbi (NEMATODA: ONCHOLAIMIDAE) in a tropical tidal flat. J. Mar. Biol. Ass. U. K., v. 83, n. 5, p. 903-904, 2003.

ESTEVES, A. M.; MARIA, T. F.; WANDENESS, A. P. Population structure of Comesoma arenae Gerlach (Nematoda, Comesomatidae) in a Brazilian tropical tidalflat, Rio de Janeiro, Brazil. Rev. Bras. Zool., v. 21, n. 4, p. 775-777, 2004.

FENCHEL, T. The ecology of micro and meiobenthos. Annu. Rev. Ecol. Syst., v. 9, p. 99-121, 1978.

FONSECA, G.; NORENBURG, J.; DI DOMENICO, M. Editorial: diversity of marine meiofauna on the coast of Brazil. Mar. Biodiv., v. 44, p. 459-462, 2014.

GIERE, O. Meiobenthology. The microscopic motile fauna of aquatic sediments. 2nd ed. Berlin, Heidelberg: Springer, $2009.527 \mathrm{p}$.

GINGOLD, R.; MOENS, T.; ROCHA-OLIVARES, A. Assessing the Response of Nematode Communities to Climate ChangeDriven Warming: A Microcosm Experiment. PLoS ONE, v. 8, n. 6, p. e66653, 2013.

GOMES, T. P.; ROSA FILHO, J. S. Composição e variabilidade espaço-temporal da meiofauna de uma praia arenosa amazônica (Ajuruteua, Pará). Iheringia, Sér. Zool., v. 99, n. 2, p. 210-216, 2009.

GOMES, T. P.; VENEKEY, V.; ROSA FILHO, J. S. Marine Nematoda from Ajuruteua beach, Amazon Coast, Brazil. Atlântica, v. 35, n. 1, p. 67-70, 2013.

HEIP, C.; VINCX, M.; VRANKEN, G. The ecology of marine nematodes. Oceanogr. Mar. Biol. Ann. Rev., v. 23, p. 399489, 1985.

MARE, M. F. A study of a marine benthic community with special reference to the microorganisms. J. Mar. BioI. Ass. U. K., v. 25, p. 517-554, 1942. 
MARIA, T. F.; SILVA, N. R. R.; WANDENESS, A. P.; ESTEVES, A. M. Spatio-temporal study and population structure of Daptonema oxycerca (Nematoda: Xyalidae) in Coroa Grande, Rio de Janeiro, Brazil. Braz. J. Oceanogr., v. 56, n. 1, p. 41-50, 2008a.

MARIA, T. F.; ESTEVES, A. M.; SMOL, N.; VANREUSEL, A; DECRAEMER, W. Nematodes from sandy beaches of Guanabara Bay, Rio de Janeiro, Brazil. Biociências, v. 16, n. 2, p. 92-103, 2008b.

MARIA, T. F.; PAIVA, P. C.; VANREUSEL, A.; ESTEVES, A. M. The relationship between sandy beach nematodes and environmental characteristics in two Brazilian sandy beaches (Baía de Guanabara, Rio de Janeiro). An. Acad. Bras. Ciênc., v. 85 , n. 1, p. 257-270, 2013a.

MARIA, T. F.; ESTEVES, A. M.; VANAVERBEKE, J.; VANREUSEL, A. Is nematode colonisation in the presence of Scolelepis in tropical sandy-beach sediment similar to the colonisation process in temperate sandy beaches? Braz. J. Biol., v. 73, n. 1, p. 19-28, 2013 b.

MARIA, T. F.; WANDENESS, A. P.; DI DOMENICO, M.; VENEKEY, V.; FALCÃO, O.; FONSÊCA-GENEVOIS, V.; DOS SANTOS, P. J. P.; ESTEVES, A. M. Monitoramento da meiofauna bentônica intermareal. In: TURRA, A.; DENADAI, M. R. (Org.). Protocolos para o monitoramento de habitats bentônicos costeiros. Instituto Oceanográfico da Universidade de São Paulo, 2015. p. 217-221.

MCLACHLAN, A. Sandy beach ecology- a review. In: MCLACHLAN, A.; ERASMUS, T. (Eds). Sandy beaches as ecosystems. Port Elizabeth: The Hauge Dr. W. Junk Publ., 1983. p. 321-380.

MCLACHLAN, A.; BROWN, A. The ecology of sandy shores. Amsterdam: Elsevier, 2006. 373 p.

MEDEIROS, L. R. A. Meiofauna da região entremarés do litoral norte do estado de São Paulo. In: 36 Reunião Anual da Sociedade Brasileira para o Progresso da Ciência, 1984, São Paulo. Ciênc. Cult., v. 34, p. 93, 1984.

MEDEIROS, L. R. A. Meiofauna de praia arenosa da Ilha Anchieta, São Paulo: I Fatores físicos. Bol. Inst. Oceanogr., v. 40, n. 1/2, p. 27-38, 1992.

MIRTO, S.; CRISTINA, M.; SINOPOLI, M.; MARICCHIOLO, G.; GENOVES, L.; VIZZINI, S.; MAZZOLA, A. Meiofauna as an indicator for assessing the impact of fish farming at an exposed marine site. Ecol. Indic., v. 18, p. 468-476, 2012.

MOELlmanN, A. M.; CORBISIER, T. N. Does touristic flow affect meiofauna of sandy beaches? Preliminary results. J. Coast. Res., v. 35, p. 590-598, 2003.

MOORE, C. G.; BETT, B. J. The use of meiofauna in marine pollution impact assessment. Zoo. J. Limn. Soc., v. 96, n. 3, p. 263-280, 1989 .

NETTO, S. A.; PAGLIOSA, P. R.; FONSECA, A. L. O.; GALLUCCI, F.; FONSECA, G. F. C.; SOUZA, R. S. Interações entre o microfitobentos, meiofauna e macrofauna (Praia Comprida, Santa Catarina). Braz. J. Ecol., v. 11, p. 78-82, 2007.

NETTO, S. A.; MENEGHEL, A. Pulse of marine subsidies: the role of surf diatom Asterionellopsis glacialis accumulations in structuring the meiofauna of sandy beaches. Mar. Biodivers., v. 44, n. 3, p. 445-457, 2014.

OLIVEIRA, E. B.; SOARES-GOMES, A. Punctual impact of a domestic sewage on intertidal meiofauna of Charitas beach, Niterói, Rio de Janeiro, Brazil. J. Coast. Res., v. 35, p. $573-$ 579,2003
PINTO, T. K. O.; SANTOS, P. J. P. Meiofauna community variation in a Brazilian tropical sandy beach. Atlântica, v. 28, n. 2, p. 117-127, 2006.

REMANE, A. Verteilung und organization der benthonischen Mikrofauna der Kieler Bucht. Wiss. Meeresuntersuchungen., v. 21, p. 161-221, 1933.

ROSA FILHO, J. S.; GOMES, T. P.; ALMEIDA, M. F.; SILVA, R. F. Benthic fauna of macrotidal sandy beaches along a smallscale morphodynamic gradient on the Amazon coast (Algodoal Island, Brazil). J. Coast. Res., v. 64, p. 435-439, 2011.

SILVA, V. M. A. P.; GROHMANN, P. A.; NOGUEIRA, C. S. R. Studies of meiofauna of Rio de Janeiro, Brazil. Coast. Zone, v. 91, n. 3, p. 2011-2022, 1991.

SILVA, V. M. A. P.; GROHMANN, P. A.; ESTEVES, A. M. Aspectos gerais do estudo da meiofauna de praias arenosas. In: ABSALÃO, R. S.; ESTEVES, A. M. (Eds.). Oecologia Brasiliensis III: Ecologia de Praias Arenosas do Litoral Brasileiro. Rio de Janeiro: UFRJ, 1997. p. 67-92.

SILVA, V. M. A. P.; MUEHE, D.; XIMENEZ, M. S. Morfodinâmica praial e meiofauna: em busca de relações: II Simpósio Nacional de Geomorfologia. Geosul, v. 14, n. 27, p. 256-259, 1999.

SOMERFIELD, P. J.; FONSÊCA-GENEVOIS, V. G.; RODRIGUES, A. C. L; CASTRO, F. J. V; SANTOS, G. A. P. Factors affecting meiofaunal community structure in the Pina Basin, an urbanized embayment on the coast of Pernambuco, Brazil. J. Mar. Biol. Ass. U. K., v. 83, n. 6, p. 1209-1213, 2003.

SOUZA-SANTOS, L.; RIBEIRO, V. S. S.; SANTOS, P. J. P.; FONSÊCA-GENEVOIS, V. G. Seasonality of intertidal meiofauna on a tropical sandy beach in Tamandaré Bay (Northeast Brazil). J. Coast. Res., v. 35, p. 369-377, 2003.

TODARO, M. A.; ROCHA, C. E. F. Diversity and distribution of marine Gastrotricha along the northern beaches of the State of São Paulo (Brazil), with description of a new species of Macrodasys (Macrodasyida, Macrodasyidae). J. Nat. Hist., v. 38, p. 1605-1634, 2004.

VANAVERBEKE, J.; LAMPADARIOU, N.; SCHRATZBERGER, M.; KUHNERT, J.; STEYAERT, M.; ADÃO, H.; BARNES, N.; CAMPINAS BEZERRA, T.; DRGAS, A.; KALEGEROPOILOU, V.; PORTUGAL, R.; SEVASTOU, K.; URBANMALINGA, B.; VANDEPITTE, L.; VEITKÖHLER, G.; WHOMERSLEY, P.; FERRERO, T. The effect of increased rainfall on the sandy beach ecosystem: results from a panEuropean experimente. In: BAYED, A. (Ed). Sandy beaches and coastal zone management - Proceedings of the Fifth International Symposium on Sandy Beaches. Rabat: Travaux de 1'Institut Scientifique, 2009. p. 143-144.

VENEKEY, V.; FONSÊCA-GENEVOIS, V. G.; SANTOS, P. J. $\mathrm{P}$. Influence of the tidal and rainfall cycles on the population structure and density of Mesacanthion hirsutum (Nematoda, Thoracostomopsidae) in a tropical sandy beach (Tamandaré Bay, Pernambuco, Brasil). Braz. J. Oceanogr., v. 59, n. 3, p. 253-258, 2011.

VENEKEY, V.; SANTOS, P. J. P.; FONSÊCA-GENEVOIS, V. G. The influence of tidal and rainfall cycles on intertidal nematodes: a case study in a tropical sandy beach. Braz. J. Oceanogr., v. 62, n. 4, p. 247-256, 2014a.

VENEKEY, V.; SANTOS, P. J. P.; FONSÊCA-GENEVOIS, V. G. Effect of environmental factors on intertidal Nematoda in a tropical sandy beach (Tamandaré Bay, Pernambuco, Brazil). J. Coast. Res., v. 30, n. 4, p. 785-794, 2014 b. 
VERÇOSA, M. M.; DOS SANTOS, P. J. P.; SOUZA, J. R. B.; DA ROCHA, C. M. C. Distribuição de Stygarctus bradypus Schulz, 1951 (Tardigrada, Heterotardigrada) na margem sul da Ilha de Itamaracá (PE, Brasil). Atlântica, v. 32, n. 1, p. 23-31, 2009.

VICTOR-CASTRO, F. J.; FONSÊCA-GENEVOIS, V.; LIRA, L.; DA ROCHA, C. M. C. Efeito da sedimentação sobre a distribuição de Batillipes pennaki Marcus, (1946) em zona tropical típica: Restinga do Paiva, Pernambuco, Brasil. Trab. Oceanog. Univ. Fed. Pernamb., v. 27, n. 2, p. 89-102, 1999.

WANDENESS, A. P.; ESTEVES, A. M.; NOGUEIRA, C. R. S.; SUBRINHO, S. Meiofauna da Zona entremarés da Praia dos Anjos, Arraial do Cabo, RJ. In: ABSALÃO, R. S.; ESTEVES, A. M. (Org.). Ecologia de Praias Arenosas do Litoral Brasileiro. Rio de Janeiro: UFRJ, 1997. p. 93-106.

WANDENESS, A. P.; ESTEVES, A. M.; FONSÊCA-GENEVOIS, V. Copepoda Harpaticoida meiobentônicos da Coroa do Avião, PE. Trab. Oceanog. Univ. Fed. Pernamb., v. 26, n. 2, p. 99-104, 1998.
ZEPPILLI, D.; SARRAZIN, J.; LEDUC, D.; ARBIZU, P. M.; FONTANETO, D.; FONTAINER, C.; GODDAY, A. J.; KRISTENSEN, R. M.; IVANENKO, V. N.; SØRENSEN, M. V.; VANREUSEL, A.; THEBAULT, J.; MEA, M.; ALLIO, N.; ANDRO, T.; ARVIGO, A.; CASTREC, J.; DANIELO, M.; FUMERON, R.; HERMABESSIERE, L.; HULOT, V.; JAMES, T.; LANGONNE-AUGEN, R.; LE BOT, T.; LONG, M.; MAHABROR, D.; MOREL, Q.; PANTALOS, M.; POUPLARD, E.; RAIMONDEAU, L.; RIO-CABELLO, A.; SEITE, S.; TRAISNEL, G.; URVOY, K.; VAN DER STEGEN, T.; WEYAN, M.; FERNANDES, D. Is the meiofauna a good indicator for climate change and anthropogenic impacts? Mar. Biodiv., v. 45, n. 3, p. 505-535, 2015 . 